\title{
HUBUNGAN POLA DIET REMAJA DENGAN STATUS GIZI
}

\section{The Correlation between Adolescence's Dietary Pattern with Nutritional Status}

\author{
Fresthy Astrika Yunita ${ }^{1)}$, Hardiningsih ${ }^{1)}$, Agus Eka Nurma Yuneta ${ }^{1)}$, Endang Sutisna \\ $S^{2)}$, Yeremia Rante Ada ${ }^{3)}$ \\ 1) Prodi D III Kebidanan, Sekolah Vokasi, Universitas Sebelas Maret \\ ${ }^{2)}$ Bagian Ilmu Kesehatan Masyarakat, Fakultas Kedokteran, Universitas Sebelas Maret \\ 3) Prodi D III Hiperkes, Sekolah Vokasi, Universitas Sebelas Maret \\ Jl. Ir. Sutami 36A Kentingan, Jebres Surakarta 57126 telp. (0271) 662622 \\ E-mail:fresh_outside@yahoo.com
}

\begin{abstract}
ABSTRAK
Latar belakang: Usia remaja cenderung mementingkan penampilan fisik. Remaja putri termasuk kelompok yang rentan mengalami masalah gizi. Remaja yang masih dalam tahap pertumbuhan terobsesi ingin memiliki penampilan fisik yang menarik dengan cara yang salah diantaranya diet ketat, latihan keras, dan asupan makan yang buruk sehingga menjadi penyebab masalah gizi pada remaja dan mempengaruhi proses tumbuh kembang. Tujuan penelitian ini adalah untuk mengetahui pola diet remaja, mengetahui status gizi remaja, dan menganalisis hubungan pola diet remaja dengan status gizi.

Subjek dan Metode: Jenis penelitian analitik observasional dengan desain penelitian cross sectional. Populasi yang digunakan adalah remaja putri di SMP 18 Surakarta .Teknik pencuplikan sampel menggunakan simple random sampling dengan jumlah sampel sebanyak 30 remaja putri. Alat ukur dalam penelitian ini adalah kuesioner dan lembar observasi. Analisis data dilakukan dengan uji statistik Kolmogorov-smirnov.

Hasil: 60\% remaja putri di SMP 18 Surakarta melakukan diet (16 responden) serta 50\% remaja putri di SMP 18 Surakarta mengalami status gizi kurus sebesar (15 responden). Berdasarkan hasil uji statistik Kolmogorov-smirnov diperoleh nilai $\mathrm{p}=0.023$ yang berarti terdapat hubungan pola diet remaja dengan status gizi.
\end{abstract}

Kesimpulan: Terdapat hubungan antara pola diet remaja dengan status gizi.

Kata kunci: Diet, Remaja, Status Gizi 


\begin{abstract}
Background: During their adolescence years, students tend to choose physical appearance. The adolescence girl is included in the group that susceptible to having a nutritional problem. Adolescence in their growth stage tend to obsessed to have an attractive appearance, but they do it in a wrong way such as doing a strick diet, extra exercising, and a poor of food supply, these things resulting in become a common cause of the nutritional problem in teenagers and affect in the process of their growth stage. The purpose of this research is to know about the adolescence's dietary pattern, adolescence's nutritional status, and relation between the diet's pattern with their nutritional status.

Subjects and Method: Observational analytics is the type of research with a crosssectional research design. The population used in this research is SMP 18 Surakarta teenage girls. The sample sampling technique is using simple random sampling. The subject of this research are 30 teenage girls. The measuring instrument in this research are questioner and observation sheet. Data analysis was performed using the KolmogorovSmirnov statistical test.

Results: 60\% of the adolescence's girls in SMP 18 Surakarta are doing a diet (16 respondent), and 50\% of the teenager girls are having a thin nutritional status (15 respondents). Based on the result of the Kolmogorov-smirnov statistical test, it is showing that $p=0.023$ which means there is a relation between the teenagers diet's pattern and their nutritional status.
\end{abstract}

Conclusion: There is a relation between the adolescence's dietary pattern with their nutritional status.

Keywords: Dietary, Adolescence, Nutritional Status

\section{PENDAHULUAN}

Sebagian remaja yang masih berada dalam masa pertumbuhan terobsesi ingin memiliki tubuh yang langsing ${ }^{[1]}$. Tapi sayangnya, banyak diantara mereka menempuh cara yang salah yaitu dengan diet ketat tanpa memperhatikan asupan gizi dan kapasitas tubuh $^{[2]}$. Cara yang salah tersebut banyak dilakukan oleh remaja yang ingin menurunkan berat badan dengan cepat sehingga berpengaruh terhadap tumbuh kembangnya. Seringkali para remaja mengganti kebiasaan baik dengan kebiasaan baru yang dianggap dapat menurunkan berat badan, seperti melewatkan waktu makan, konsumsi minuman tertentu, membiarkan tubuh puasa untuk waktu lama, dan terlalu keras ketika berolahraga $^{[3]}$.

Status gizi adalah salah satu indikator untuk menilai status kesehatan remaja dengan cara yang mudah dan murah dimana yang dibutuhkan hanya disiplin dan komitmen untuk secara rutin dan kontinu memantau berat badan dan tinggi badan. Status gizi pada remaja dihitung dengan menggunakan rumus indeks massa tubuh atau yang biasa disingkat dengan istilah IMT atau BMI (Body Mass Index) ${ }^{[2],[4],[5]}$.

Remaja dengan emosi yang menggebu kerap mengambil keputusan gegabah tanpa mempertimbangkan risiko dan konsekuensi di masa mendatang ${ }^{[6]}$. Termasuk saat merasa tubuhnya terlalu gemuk sehingga membuatnya kurang percaya diri ${ }^{[7]}$. Remaja cenderung dengan mudah memutuskan untuk menghentikan asupan makanan ke dalam tubuhnya dan berharap berat badannya bisa segera turun. Hanya saja, usia remaja pada dasarnya masih membutuhkan asupan nutrisi untuk mendukung pertumbuhannya. Sehingga metode diet yang salah dikhawatirkan akan membuat proses pertumbuhan menjadi terkendala dan memicu timbulnya masalah kesehatan $^{[8]}$. Berdasarkan hal tersebut di atas peneliti tertarik untuk 
mengetahui hubungan pola diet remaja dengan status gizi.

$\frac{\text { SUBJEK DAN METODE }}{\text { Jenis penelitian ini adalah analitik }}$
observational dengan desain cross sectional untuk mengetahui hubungan pola diet remaja dengan status gizi. Variabel bebas pada penelitian ini adalah pola diet remaja, sedangkan variabel terikat pada penelitian ini adalah status gizi. Teknik sampling yang digunakan pada penelitian ini adalah simple random sampling. Penelitian dilakukan di SMP Negeri 18 Surakarta dengan jumlah sampel sebanyak 30 remaja perempuan.

Alat ukur dalam penelitian ini yaitu kuesioner yang diberikan secara langsung kepada remaja putri meliputi identitas dan pola diet remaja putri. Sedangkan untuk menentukan status gizi remaja menggunakan lembar observasi. Analisis data dilakukan secara komputerisasi menggunakan program SPSS 20.0 dengan uji statistik Kolmogorov-Smirnov.

\section{Analisis Univariat}

\section{HASIL}

Analisis variabel penelitian secara univariat menjelaskan tentang distribusi variabel penelitian yang meliputi variabel pola diet remaja dan status gizi.

Tabel 1. Tabel Univariat Variabel

\begin{tabular}{lcccc}
\hline \multicolumn{1}{c}{ Variabel } & \multirow{2}{*}{$\mathbf{~}$} & $\boldsymbol{2}$ & \multicolumn{2}{c}{ Total } \\
& & & n & \% \\
\hline Pola diet & 18 & 60 & & \\
Ya & 12 & 40 & 30 & 100 \\
Tidak & & & & \\
Status gizi & 15 & 50 & & \\
Kurus & 11 & 36.7 & 30 & 100 \\
Normal & 3 & 10 & & \\
Gemuk & 1 & 3.3 & & \\
Obesitas &
\end{tabular}

Tabel 1 menunjukkan bahwa mayoritas responden yang diteliti melakukan diet yaitu sebesar 18 responden $(60 \%)$ dan sebanyak 15 responden $(50 \%)$ memiliki status gizi kurus.

\section{Analisis Bivariat}

Analisis variabel penelitian secara bivariat menggunakan uji statistik Kolmogorovsmirnov untuk menjelaskan hubungan hubungan pola diet remaja dengan status gizi.

Tabel 2. Tabel Bivariat Variabel

\begin{tabular}{|c|c|c|c|c|c|}
\hline \multirow{2}{*}{ Variabel } & \multirow{2}{*}{$\mathbf{n}$} & \multirow{2}{*}{$\%$} & \multicolumn{2}{|c|}{ Total } & \multirow{2}{*}{$\mathbf{P}$} \\
\hline & & & $\mathrm{n}$ & $\%$ & \\
\hline \multicolumn{6}{|l|}{ Pola diet } \\
\hline Ya & 18 & 60 & & & \\
\hline Tidak & 12 & 40 & 30 & 100 & \\
\hline $\begin{array}{l}\text { Status } \\
\text { gizi }\end{array}$ & & & & & 0.023 \\
\hline Kurus & 15 & 50 & 30 & 100 & \\
\hline Normal & 11 & 36 & 30 & 100 & \\
\hline Gemuk & 3 & 10 & & & \\
\hline Obesitas & 1 & 3.3 & & & \\
\hline
\end{tabular}

Tabel 2 menunjukkan bahwa terdapat hubungan pola diet remaja dengan status gizi dengan nilai $\mathrm{p}=0.023$.

\section{PEMBAHASAN}

Masa remaja berada dalam rentang usia 10-19 tahun. Remaja merupakan masa peralihan dari masa anak-anak menuju dewasa dan disertai dengan perubahan dalam aspek kognitif, emosi, sosial, dan moral. Remaja juga mengalami perkembangan psikologis dan perubahan fisik yang cepat ${ }^{[9]}$. Kebanyakan remaja, khususnya remaja putri ingin tampil dengan tubuh yang langsing dengan cara melakukan diet karena remaja selalu merasa tidak puas terhadap keadaan dirinya sendiri ${ }^{[10]}$. Oleh karena itu, para remaja sibuk memperhatikan kondisi bentuk tubuhnya sehingga hasil penelitian menunjukan $60 \%$ dari responden melakukan pembatasan jumlah makanan atau diet.

Perilaku diet yang berlebihan pada remaja berkaitan dengan perhatian kepada tubuh yang berlebihan dan ketidakpuasan pada citra tubuh remaja itu sendiri ${ }^{[8]}$. Hal ini dikarenakan perubahan fisik dan bentuk tubuh yang terjadi pada masa pubertas merupakan hal yang sensitif dan penting bagi remaja. Oleh karena itu, 
masalah yang berkaitan dengan penampilan fisik dapat memengaruhi citra tubuh dan kepuasan pada tubuh yang pada akhirnya akan berdampak pada perilaku konsumsi makanan dan pengendalian berat badan ${ }^{[11]}$. Di sisi lain, remaja dengan rasa percaya diri rendah mudah mendapat tekanan dari lingkungan sekitar yang memengaruhi pandangan terhadap citra tubuhnya sehingga memengaruhi sikap dan perilaku makan remaja sehari-hari ${ }^{[12]}$ yang berdampak pada kurangnya asupan gizi pada remaja perempuan ${ }^{[13]}$.

Status gizi merupakan manifestasi keadaan tubuh yang dapat mencerminkan hasil dari makanan yang dikonsumsi setiap hari. Konsumsi makanan yang tidak memenuhi kecukupan akan mengakibatkan terjadinya kekurangan gizi $^{[14]}$. Hasil penelitian menemukan sebanyak 15 responden (50\%) mengalami gizi kurang atau kurus, sedangkan responden dengan gizi normal sebanyak 11 responden $(36,7 \%)$, gizi gemuk 3 responden (3\%), serta obesitas 1 responden $(1 \%)$.

Hubungan pola diet remaja dengan status gizi dalam penelitian ini dianalisis menggunakan uji statistik Kolmogorovsmirnov dan diperoleh hasil $\mathrm{p}=0.023$ yang menunjukkan bahwa terdapat hubungan pola diet remaja dengan status gizi. Hal ini sejalan dengan ${ }^{[15]}$ yang menemukan bahwa perilaku makan memiliki hubungan yang bermakna dengan status gizi remaja perempuan. Perilaku diet berlebihan seperti olahraga berlebihan, konsumsi obat pencahar atau diuretik, pembatasan konsumsi makanan yang berlebihan, dan memuntahkan makanan secara sengaja memiliki risiko yang lebih besar untuk mengalami gangguan makan ${ }^{[8]}$. Hal ini sejalan dengan ${ }^{[14]}$ yang menyatakan bahwa praktik diet yang ketat pada remaja akan meningkatkan risiko status gizi buruk dan eating disorder, yaitu anorexia nervosa atau bulimia nervosa.

Remaja sering membatasi konsumsi makanan dengan pola konsumsi yang tidak sesuai dengan kaidah ilmu gizi. Hal tersebut dapat berdampak pada peningkatan risiko anemia karena pada usia remaja terjadi peningkatan kebutuhan zat gizi mikro (zat besi dan asam folat ${ }^{[16],[17]}$. Kerentanan remaja terhadap anemia berhubungan dengan pertumbuhan fisik yang cepat dan hilangnya zat gizi mikro akibat menstruasi pada remaja perempuan. Selain itu, pengaturan pola makan yang salah merupakan kontributor utama terjadinya anemia. Remaja perempuan yang mengonsumsi sedikit jenis makanan memiliki prevalensi lebih tinggi mengalami anemia. Dampak buruk anemia tidak hanya pada pertumbuhan fisik saja, tetapi juga menghambat mencapai potensi penuh remaja yaitu mengurangi prestasi pendidikan dan produktivitas masa remaja ${ }^{[17]}$.

Dampak lain yang disebabkan dari pembatasan konsumsi makanan adalah terjadinya Kekurangan Energi Kronis (KEK) pada remaja putri. Secara umum kejadian KEK tidak hanya dipengaruhi oleh asupan energi dan protein, namun semua zat gizi dapat memberi kontribusi terhadap kejadian ini. ${ }^{[16]}$. Remaja yang mengalami KEK memiliki risiko yang lebih besar untuk mengalami penyakit infeksi dan gangguan hormonal yang memberikan dampak negatif bagi $\operatorname{tubuh}^{[13]}$.

Orang tua dan lingkungan sekitar memegang peranan penting dalam mentalitas standar diet dan bentuk tubuh yang ada di masyarakat dan media. Hal penting yang perlu dilakukan adalah mendukung dan mendorong untuk memiliki hubungan yang sehat dengan cara menyediakan makanan yang sehat sesuai kebutuhan gizi remaja serta menghindari pemberian nilai terhadap bentuk tubuh remaja ${ }^{[18]}$. Selain itu, konseling mengenai citra tubuh positif perlu diberikan kepada remaja untuk mencegah diet yang tidak sesuai sehingga dapat mencegah terjadinya penyakit yang disebabkan oleh kekurangan gizi. Citra 
tubuh positif pada remaja dapat menurunkan perilaku gangguan makan termasuk diet yang berlebihan ${ }^{[19]}$.

\section{SIMPULAN}

Berdasarkan hasil penelitian dapat disimpulkan bahwa terdapat hubungan pola diet remaja dengan status gizi dengan nilai $\mathrm{p}$ sebesar 0.023 menggunakan uji statistik Kolmogorov-smirnov.

\section{SARAN \\ Bagi Remaja Putri \\ Remaja putri hendaknya mengatur pola makan dengan baik supaya kebutuhan gizi terpenuhi serta menghindari KEK yang dapat berakibat buruk terhadap kesehatan.}

\section{Bagi Petugas Kesehatan}

Petugas kesehatan diharapkan dapat memberikan sosialisasi berkala tentang pola makan yang baik untuk menunjang tumbuh kembang remaja khususnya remaja perempuan. Selain itu deteksi status gizi remaja dapat dilakukan secara berkala di sekolah untuk mencegah gizi kurang dan gizi lebih pada remaja akibat kesalahan pola diet.

\section{Bagi SMP N 18 Surakarta}

Pihak SMP N 18 Surakarta diharapkan dapat melakukan sosialiasi pengaturan pola makan yang baik dan seimbang pada remaja dan orang tua agar orangtua memahami pentingnya mengetahui pola diet yang baik untuk menunjang status gizi remaja.

\section{DAFTAR PUSTAKA}

1. Dieny FF. 2014. Permasalahan gizi pada remaja putri. Graha Ilmu: Yogyakarta.

2. The United Nations Children's Fund (UNICEF). 2019. Aksi bergizi hidup sehat sejak sekarang untuk remaja kekinian.

https://www.unicef.org/indonesia/med ia/2806/file/Aksi-Bergizi-Siswa2019.pdf - Diakses 09 November 2019.

3. Voelker D, Reel J, Greenleaf C. 2015. Weight status and body image perceptions in adolescents: current perspectives. Adolescent Health, Medicine and Therapeutics, 149. doi:10.2147/ahmt.s68344

4. Kementerian Kesehatan Republik Indonesia. 2017. Penilaian Status Gizi. http://bppsdmk.kemkes.go.id/pusdiksd $\mathrm{mk} / \mathrm{wp}-$ content/uploads/2017/11/PENILAIAN -STATUS-GIZI-FINAL-SC.pdf Diakses 09 November 2019.

5. Lawson JA, Rennie DC, Dosman JA, Cammer AL, Senthilselvan A. 2013. obesity, diet, and activity in relation to asthma and wheeze among rural dwelling children and adolescents. Journal of Obesity. Volume 2013. Doi: http://dx.doi.org/10.1155/2013/315096

6. Herlina. 2013. Bibliotheraphy: mengatasi masalah anak dan remaja melalui buku. Bandung: Pustaka Cendekia Utama. http://file.upi.edu/Direktori/FIP/JUR._ PSIKOLOGI/196605162000122HERLINA/PERKEMBANGAN\%20 MASA\%20REMAJA.pdf - Diakses 09 November 2019.

7. A'la N, Khairani M, Nurafni. 2014. perbedaan kepercayaan diri ditinjau dari keikutsertaan program penurunan berat badan pada remaja obesitas. Jurnal Psikologi Unsyia, Vol. 2, No. 3 Juni 2014.

8. Cruz-Sáez S, Pascual A, Salaberria K, Etxebarria I, Echeburúa E. 2013. Risky eating behaviors and beliefs among adolescent girls. Journal of Health Psychology, 20(2), 154163. doi:10.1177/1359105313500683

9. Kusmiran. 2012. Kesehatan reproduksi remaja dan wanita. Jakarta: Salemba Medika.

10. Anwar. 2006. Gizi seimbang untuk remaja dan wanita usia subur dalam buku hidup sehat gizi seimbang dalam siklus kehidupan manusia. Jakarta: PT Primamedia Pustaka. Pp: 108-210

11. Kang MH, Choue RW. 2010. Relationships of body image, body 
stress and eating attitude, and dietary quality in middle school girls based on their BMI. Korean Journal of Nutrition. 2010;43:285-293. https://doi.org/10.4163/kjn.2010.43.3. 285.

12. Hyun MY, Jung YE, Kim MD, Kwak YS, Hong SC, Bahk WM, Yoo B. 2014. Factors associated with body image distortion in korean adolescents. Neuropsychiatric Disease and Treatment, 797. doi: $10.2147 /$ ndt.s63143.

13. Kementerian Kesehatan Republik Indonesia. 2018. Kenali masalah gizi yang ancam remaja indonesia. https://www.depkes.go.id/article/view/ 18051600005/kenali-masalah-giziyang-ancam-remaja-indonesia.html Diakses 09 November 2019.

14. Supriasa IGN. 2014. Penilaian status gizi. Jakarta: EGC.

15. Yusintha AN, Adriyanto. 2018. Hubungan antara perilaku makan dan citra tubuh dengan status gizi remaja putri usia 15-18 tahun. Amerta Nutrition. DOI 10.2473/amnt.v2i2.2018.147-154.

16. Arisman. 2009. Gizi dalam daur kehidupan. Jakarta: Penerbit Buku Kedokteran EGC. https://bidanku.com/panduan-dietsehat-untuk-anak-remaja-yang-aman| Bidanku.com.Diakses pada tanggal 10 April 2019.

17. Chalise B, Aryal KK, Mehta RK, Dhimal M, Sapkota F, Mehata S, Sawyer S. 2018. Prevalence and correlates of anemia among adolescents in nepal: findings from a nationally representative crosssectional survey. PLOS ONE, 13(12), e0208878. doi:10.1371/journal.pone.0 208878.

18. Kagie M. 2018. Preventing eating disorders by promoting media literacy and rejecting harmful dieting based mentalities. Intuition: The BYU Undergraduate Journal in Psychology, Vol. 13, Issue 1, Article 6. scholarsarchive.byu.edu/cgi/viewconte nt. cgi ?article $=1238 \&$ context $=$ intuition

19. Linardon J, Mitchell S. 2017. Rigid dietary control, flexible dietary control, and intuitive eating: evidence for their differential relationship to disordered eating and body image concerns. Eating Behaviors. Vol. 26, 2017, Hlm: 16-22. Doi: https://doi.org/10.1016/j.eatbeh.2017.0 1.008 . 